\title{
THE DISCURSIVE CONSTRUCTION OF CERTAINTY AND UNCERTAINTY IN THE SCIENTIFIC TEXTS OF FORENSIC PSYCHIATRY
}

Rosa Scardigno

ORCID: 0000-0002-5725-6483

Scopus Author ID: 38862931400

rosa.scardigno@uniba.it

University of Bari Aldo Moro, Italy

Ignazio Grattagliano

ORCID: 0000-0001-5929-5868

Scopus Author ID: 56738914000

ignazio.grattagliano@uniba.it

University of Bari Aldo Moro, Italy

Amelia Manuti

ORCID: 0000-0001-5308-7494

Scopus Author ID: 38862224500 amelia.manuti@uniba.it

University of Bari Aldo Moro, Italy

Giuseppe Mininni

Scopus Author ID: 35300189100

giuseppe.mininni@uniba.it

University of Bari Aldo Moro, Italy

Received January 15, 2020; Revised April 4, 2020; Accepted April 16, 2020

\begin{abstract}
A common ground between mental health and judicial-legal domains concerns concepts like "care", "control” and "possibility to foresee" human behaviour, with particular reference to the "social dangerousness". The connections between these sense-making practices can be traced by discursive modulation of "certainty/uncertainty". This study aimed to highlight the discursive peculiarities of a specific socio-cultural context and genre, namely scientific papers. The corpus of data consisted in a selection of 30 papers published by the BJP (from 1975 to 2015), on subjects concerning forensic psychiatry, subjected to Content Analysis and Critical Discourse Analysis. Results showed that the papers adopted two main socio-epistemic rhetorics. On one side, the enunciators proceeded in an "assertive" and rigorous manner through a social-epistemic rhetoric of "reassurance"; on the other side, they gave voice to rhetoric of the "limit", lacking any cognitive "closure".

Keywords: scientific communication, certainty/uncertainty, socio-epistemic rhetoric, diatextual analysis.
\end{abstract}

(C) Scardigno, Rosa; Grattagliano, Ignazio; Manuti, Amelia; Mininni, Giuseppe, 2020. This is an Open Access article distributed under the terms and conditions of the Creative Commons Attribution 4.0 International Licence (http://creativecommons.org/licenses/by/4.0).

East European Journal of Psycholinguistics, 7(1), 156-170. https://doi.org/10.29038/eejpl.2020.7.1.sca 
Скардіньйо, Роса; Гратальяно Ігнаціо, Мануті Амелія, Мінінні Джузеппе. Дискурсивне конструювання визначеності та невизначеності у наукових текстах криміналістичної психіатрії.

Анотація. Точки дотику між психічним здоров'ям та судово-юридичною сферою включають такі концепти як «увага», «контроль» i «можливість передбачати» людську поведінку 3 конкретною прив'язкою до «соціальної небезпеки». Зв'язки між цими смислоутворювальними практиками можна простежити за допомогою дискурсивної модуляції «визначеність/невизначеність». Мета цього дослідження - висвітлити дискурсивні особливості особливого соціо-культурного контексту і жанру, а саме, наукових праць. Корпус даних включає вибірку із 30 наукових праць, опублікованих ВJP (з 1975 по 2015 р.) на теми, що стосуються криміналістичної психіатрії, і до яких було застосовано контент-аналіз та критичний дискурс-аналіз. Результати засвідчили, що в наукових працях обрано дві провідні соціо-епістемічні риторики. 3 одного боку, мовці розпочинали рішуче та суворо, використовуючи соціально-епістемічну риторику «заспокоєння», 3 іншого боку, вони озвучували риторику «обмеження», позбавлену будь-якого когнітивного «завершення».

Ключові слова: наукова комунікачія, визначеність/невизначеність, сочіо-епістемічна риторика, діатекстуальний аналіз.

\section{Introduction}

This paper analysed some of the connections between two sense-making domains - the medical-psychiatric one and the legal one - evidencing the relationships between language, cognition and society. The research perspective adopted aimed to trace these connections through the discursive modulation of "certainty/uncertainty" featuring text-and-talk in interaction (Cantarini, Abraham, \& Leiss, 2014). Accordingly, the research question that guided the study was focused on the interface between discursive psychology, social psychology, health psychology, forensic psychology and psychiatry (Mininni, Scardigno, \& Grattagliano, 2014): if and to what extent did uncertainty feature psychiatric scientific texts when (mental) health problems intersect the judicial-legal horizon?

\subsection{The discursive construction of the "social dangerousness" of the "mentally-ill"}

The complex questions deriving from deviant and criminal human actions ask for new knowledge and languages emerging from the connections between Psychology/Psychiatry and Justice. Hence, when these disciplines need to converge, a particular "question of method" emerges, it concerns the distinction between clinical truth and legal truth (Grevi, 2006). The assessment of the clinical truth is the result of a psychological-psychiatric investigation, aimed to establish whether a certain person's discursive acts and behaviors are the expression of mental functions altered by either a psychiatric pathology or cognitive and/or affective-relational sphere.

Ascertaining the legal truth is the exclusive job and pertinence of the magistrate who must jus-dicere. A judge therefore "performs the law" by acquiring proofs (interrogations, inspections, witness statements, reports, admissions, objective feedback, etc.), most of which have a discursive nature. Their main objectives are to reconstruct the facts-crime in all its constituting moments and to 
attribute any single, specific and clear responsibility.

Despite the exposed differences, a possible common discursive field concerns the connection among concepts like "care", "control" and the "possibility to foresee" human conducts, especially concerning deviant behavior, aggressiveness and violence. This connection is portrayed in the concept of "social dangerousness" (Shah, 1978; Steadman \& Cocozza, 1974). It indicates the probability that a subject - already condemned as guilty and responsible by the judge - commits the crime again (with all its consequences in terms of custodial and non-custodial security measures and punishments stripping or limiting freedom), on behalf of the whole community.

Social dangerousness has two sides: the first one is only judicial. As such, it concerns subjects who were in the right mind when the crime was committed. The assessment of the probability they commit again a crime is therefore exclusively performed by the magistrate. The second one is legal medical and psychiatric, or psychological-forensic. It concerns subjects crippled by mental illness, and thus insane, when the fact happened. In this case, the probability of repeating a crime is assessed by the opinion of clinical and forensic psychologists. As for these problems, Law asks to Psychiatry, Clinical Psychology and Forensics for a broad control and social reasь 6 between control, care and predictability of human behavior increases the needs for measures limiting freedom for subjects affected by mental infirmity who committed a crime (Foucault, 1972) in the name of safety and social reassurance. The requests for certainty and probabilities that the Law makes to Psychiatry and Psychology, emphasize the complex relations between the claims for social defense - inherent the "social dangerousness" - and more wide-ranging therapeutic-rehabilitative opportunities, which must be guaranteed to the "dangerous lunatic".

An evolutional path can be traced from "danger" meant as an almost "natural" individual feature - intrinsic and unrelated to the treatment - to the so-called "conditioned to the cures". This conceptual turn grants several therapeutic possibilities but, on the other side, asks forensic and clinical psychiatrist and psychologist for new obligations, commitments and responsibilities (Catanesi, Carabellese, \& Grattagliano, 2009).

There is a wide literature about the risk factors of violent behavior. Firstly, several investigations denounced increasing risks in patients affected by serious mental pathologies (Lindqvist \& Allebeck, 1990; Marzuk, 1996) in several sociocultural contexts (Lamb \& Weimberger, 1998; Kaliski, 2002). In addition, researchers identified several risk factors that differently combined can significantly increase the probability of new violent acts. The most significant ones are: being male, schizophrenics (Walsh, Buchanan, \& Fahy, 2002), affected by serious psychotic hallucinations (Junginger, 1996) or, anyway, with a heavy clinical history (Torrey, 1994).

Other factors significantly related to the risk of violent behavior are poor adherence to treatment and substance abuse (if the two factors are correlated, the risk further increases), as well as the association between substance abuse and 
mental illness (Monahan, 1997; Swanson, Estroff, Swartz, Borum, Lachicotte, Zimmer, \& Wagner, 1997; Swartz, Swanson, \& Hiday, 1998; Rasanen, Tiihonen, \& Isohanni, 1998; Mullen, 2000; Bennett, Holloway, \& Farrington, 2008).

This survey of the literature, interweaving the languages of law and the forensic psychological and psychiatric sciences, shows the possibility of formulating scientifically-oriented opinions, albeit with different degrees of certainty, on social dangerousness as possible predictions of violent behavior. In view of the above, the main aim of the present study was to analyse some of the claims underlying these "two orders of sense-making" which share the challenge of social dangerousness. The study was intended to investigate if and to what extent some of the most consolidated discursive practices and linguistic registers used in this context were compatible with the expectations rooted into a specific socio-cultural context, that is the scientific community. Therefore, the study attempted to determine the lexical forms and the rhetoric-argumentative strategies that discursively organize the construction of knowledge in the forensic psychiatry environment.

\subsection{The discursive plot of the "social dangerousness" of the mentally ill}

Different linguistic-rhetoric modes construct traces of certainty and other ones, in a complementary manner, limit the applicability of the knowledge. Yet, a further question concerned the construction of the authors of scientific texts as socially "credible" sources. It is widely recognized that a scientific paper is legitimated as a declaratory act of sense-making by being assessed, controlled and classified within a scientific community. It is also indirectly recognized valid if it legitimizes the application of knowledge to real contexts of life and work.

\section{Methods}

\subsection{Corpus, research question and data analysis}

The corpus of data of the present study was a sample of 30 papers published by the prestigious British Journal of Psychiatry (BJP) ${ }^{1}$ in the period from 1975 to 2018. We selected articles whose main subject was forensic psychiatry.

The articles were examined according to a dual procedure. Firstly, content analysis was carried out with the support of the T-Lab software (Lancia, 2004). Content analysis allowed to detect the occurrences and co-occurrences of the recurring lemma in the texts, following the intuitive hypothesis that a greater frequency of words corresponds to more argumentative salience, without forgetting that the meaning of a linguistic sign is always dynamic and contextual (Salvatore \& Valsiner, 2011; Salvatore et al., 2017; Valsiner, 2007).

Therefore, on a second step, the corpus of data was subjected to a "diatextual" way of Critical Discourse Analysis (Fairclough, 2003; van Dijk, 2008; Wodak \& Meyer, 2009), a perspective based on the understanding of language as a "social practice" profoundly embedded within the context of production.

\footnotetext{
${ }^{1}$ As reported in the homepage of its website, the British Journal of Psychiatry (BJP) is one of the world's leading psychiatric journals. It addresses to psychiatrists, clinical psychologists, and all professionals with an interest in mental health.
} 
Using the "diatextual" lens within Critical Discourse Analysis (Mininni \& Manuti, 2017; Mininni, Manuti, Scardigno, \& Rubino, 2014), means firstly to highlight the "genre" of the discourse (Bakhtin, 1979). In this vein, the corpus of data analysed by the present study can be categorized as a special genre - namely that of scientific texts - answering to quite rigid criteria that define what is appropriate and widely accepted by a community of experts. Scientific texts can be conceived as a discursive event owing a peculiar argumentative intent, because they are the privileged means to introduce new discoveries into the scientific communities, to invite other scholars to share them and to accept or defend specific claims, to widespread any new knowledge (Hyland, 2001).

In view of the above, the research question that guided the study was to investigate if and to what extent did uncertainty feature psychiatric scientific texts when (mental) health problems intersect the judicial-legal horizon. Therefore, in line with this aim, data analysis was addressed to investigate how uncertainty was discursively constructed within these texts. In our opinion, the social dangerousness of the psychically ill is featured by an "order of the discourse" (Foucault, 1972) which engages forensic psychiatrists/psychologists on two levels: on the one hand, they are obliged to construct "certainties" on a theoretical-methodological level, which is shared by their scientific community. On the other hand, the references to the "dangerous mentally-ill person" could be dotted with many traces of uncertainty for two main reasons: first, the discursive "genre" involves variable levels of assertiveness; second, these matters bear a great responsibility for their applicative implications on judicial, ethical and social levels.

\subsection{Interpretative Models}

In view of a Critical Discourse Analysis we performed both bottom-up and topdown paths in order to achieve a more holistic reading of the data (Mininni, Manuti, Scardigno, \& Rubino, 2014). Specifically, the interpretative models that responded to the research objectives and to the typology of texts, were firstly determining a "socio-epistemic rhetoric" (Berlin, 1993). This construction incorporates references to both the sociological tradition of the analysis of the "ideologies" and the semiotic investigation of the "sign systems". Therefore, this interpretative tool permits a topdown reading of the texts and can determine sense perspectives valid for specific groups of positioning. The fecundity of this construction firstly derives from the sense of the word 'rhetoric' that, in our cultural pre-construction, evokes both preoccupation and care for the word, as well as interest for the "style", that is the connecting category between the linguistic and psychological domains (Caffi, 2001).

For a bottom-up analysis, we proposed the discursive modulation analyzed by the pragmatic construct of "mitigation", meant as the efforts to lower one or more parameters of interactions (ivi). This "reduction" may basically occur on three levels, determined by Caffi with three images: as a reduction of the propositional content, when the enunciators hide behind "bushes"; as attenuation of the illocutionary force, when they protect themselves using "hedges"; as keeping 
distance from the actantial or space-time viewpoint, when they enjoy the reserved nature guaranteed by the "screens". Other analytical tools concern non-propositional aspects, e.g. the expressions of comment and reformulation that, by acting as a “meta-discourse” (Crismore, Markannen, \& Steffenson, 1993; Hyland, 1996; 1998), enable the receiver not only to organize the text coherently, but also to understand the enunciator's credibility.

\section{Results}

\subsection{Content Analysis}

The social-epistemic rhetoric was firstly incardinated on a lexicon. The tool "vocabulary" granted by the T-Lab software allowed to point out the most widely used lemmas in the BJP texts, along with their absolute frequencies, in order to better understand the extent to which the papers examined were focused on issues related to forensic psychiatry. As expected, the most frequent words brought out three domains of meaning (see Table 1).

Table 1

Most used lemmas in the BJP texts and relevant absolute frequencies

\begin{tabular}{lclclc}
\hline Research & Frequency & $\begin{array}{l}\text { (Forensic) } \\
\text { Psychiatry }\end{array}$ & Frequency & $\begin{array}{l}\text { Social } \\
\text { Dangerousness }\end{array}$ & Frequency \\
\hline Study & 546 & Disorder & 823 & Risk & 472 \\
Factor & 321 & Mental & 425 & Criminal & 356 \\
Population & 307 & Patients & 404 & Violence & 346 \\
Data & 233 & Personality & 369 & Offence & 333 \\
Man & 225 & Behaviour & 306 & Violent & 248 \\
Woman & 208 & Health & 247 & Antisocial & 245 \\
Age & 200 & Psychiatric & 245 & Crime & 237 \\
& & Schizophrenia & 230 & Homicide & 237 \\
\hline
\end{tabular}

The first semantic area referred to the activity of "research" in general, like basic social records ('sex' and 'age'). References to mental, behavioral and personality factors evoked the investigated disciplinary framework that is (forensic) psychiatry. In general, illness was identified as 'disorder', whereas 'schizophrenia' was the most specific diagnosis proposed by the corpus of articles. The mention to 'health' was fundamental in order to show the utility and the social importance of the focused subjects and the topics. Reference to violence, criminality and antisocial behavior provided the backdrop to "social dangerousness". The words 'risk' and 
'homicide' as well as 'crime' and 'offence' highlighted both the pragmatic dimension and the social threat.

In order to examine the semantic networks activated in relation to specific words, defined as "focus" and chosen according to their frequency and saliency, the T-lab tool "word associations" was used. It allowed the statistic validity of the links between the lemmas to be verified in the elementary contexts (the periods) by calculating the cosine coefficient.

Figure 1

Word association - focus on word 'Psychiatric'

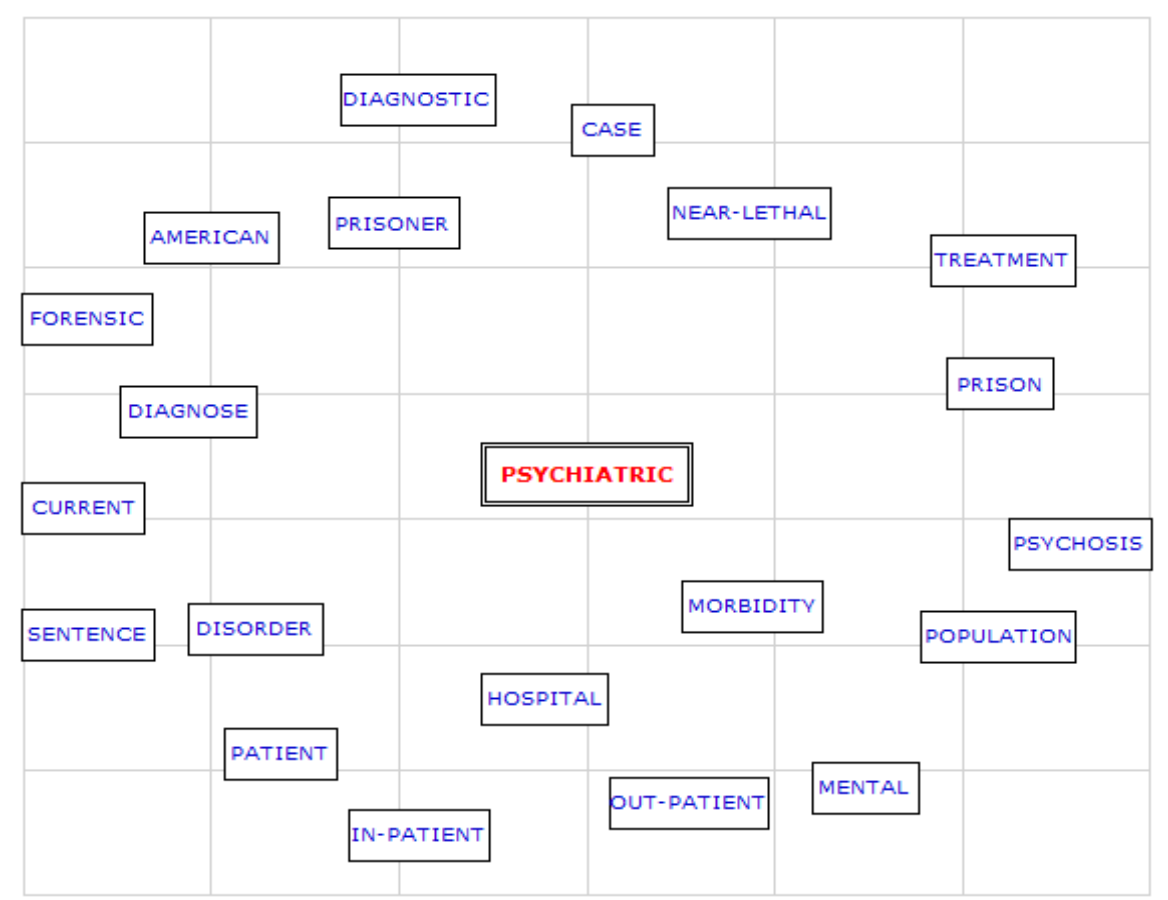

The emerging graph allowed us to point out the efforts to compose differing conceptual frameworks: the identification of persons as 'patients' and 'prisoners', the contexts of 'hospital' and 'prison', the presence of a lexicon referring both to the medical world - 'diagnose', 'diagnostic', 'treatment', 'morbidity' - and to the forensic domain - 'forensic', 'sentence' - highlight the complexity and the need to consider different theoretical-methodological perspectives.

This "dual" dimension also characterized the semantic network about the word 'health'. On the one hand, it appeared to be rooted in the public and social dimension ('service', 'public', 'department', 'problem', 'national', 'world', 'England'); on the other, it highlighted references to the forensic environment ('security', 'justice'). More generally, health was engaged in the need for its "management” ('care', 'prevention', 'information', 'system', 'initiative', and 'professional').

Content Analysis therefore revealed the holistic orientation of these scientific texts: this result both integrated the various disciplinary prospects, underlining at the same time the dialectic nature of argumentation. 
Figure 2

Word association - focus on word 'Health'

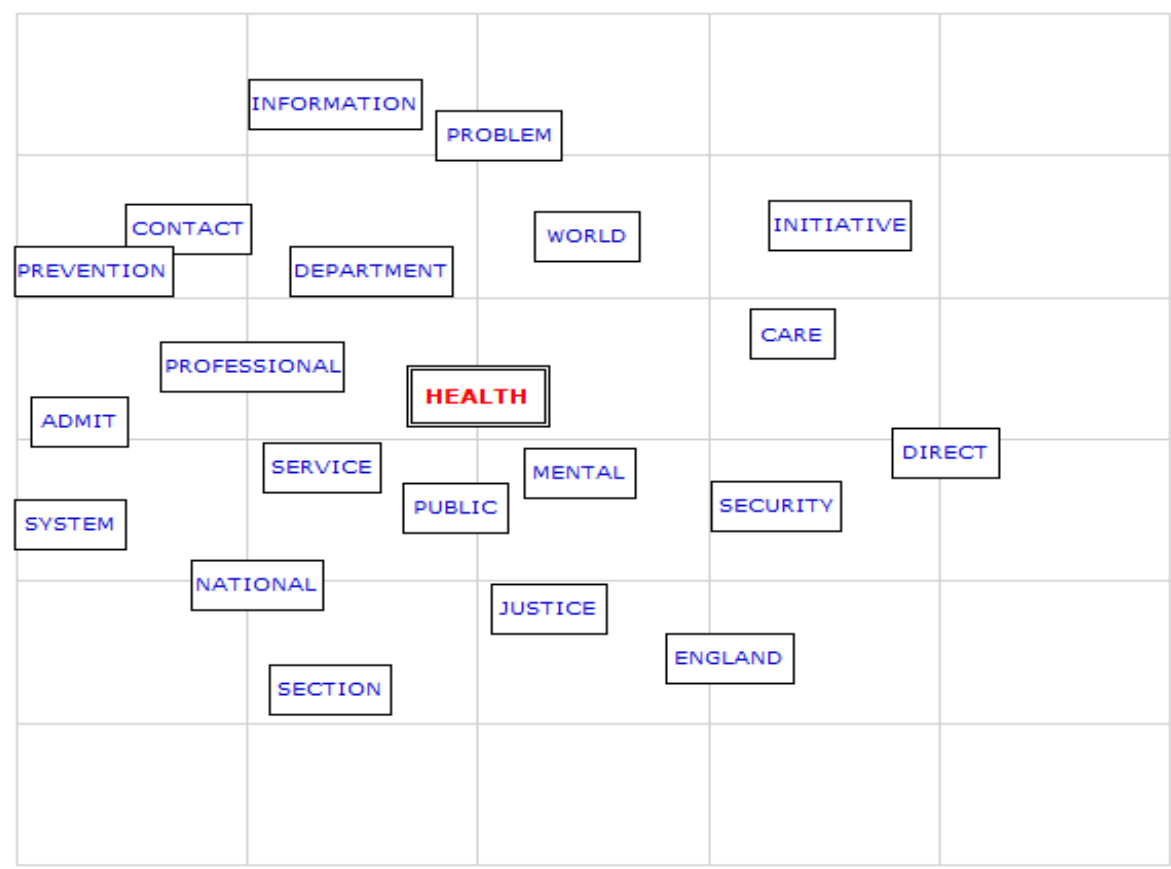

The semantic networks regarding the lemmas 'mental' and 'crime' reveal a particular dynamic between logoi and antilogoi: the two closest words to the former were 'illness' and 'health', the closest ones to the latter were 'violent' and 'nonviolent'.

Figure 3

Word association - focus on word 'Mental'

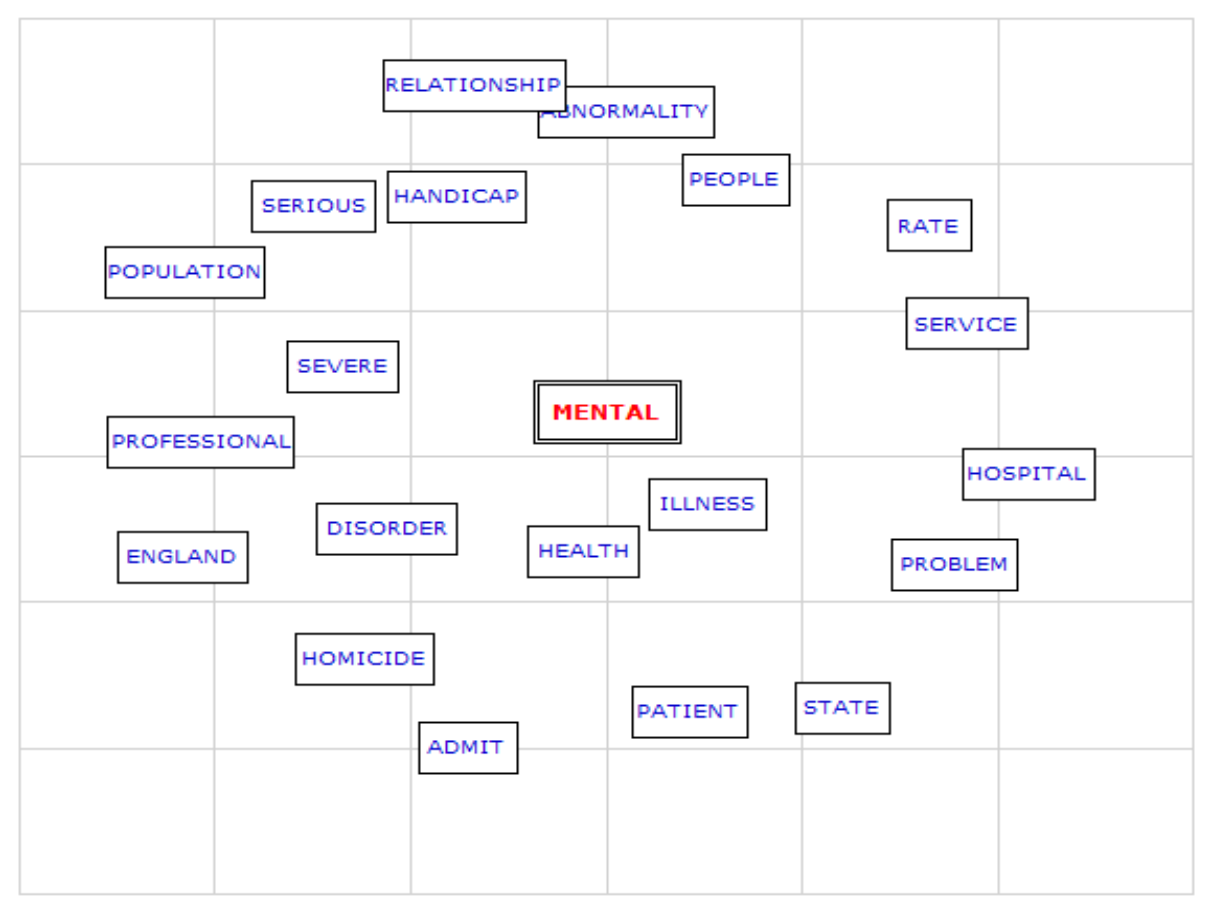


Figure 4

Word association - focus on word 'Crime'

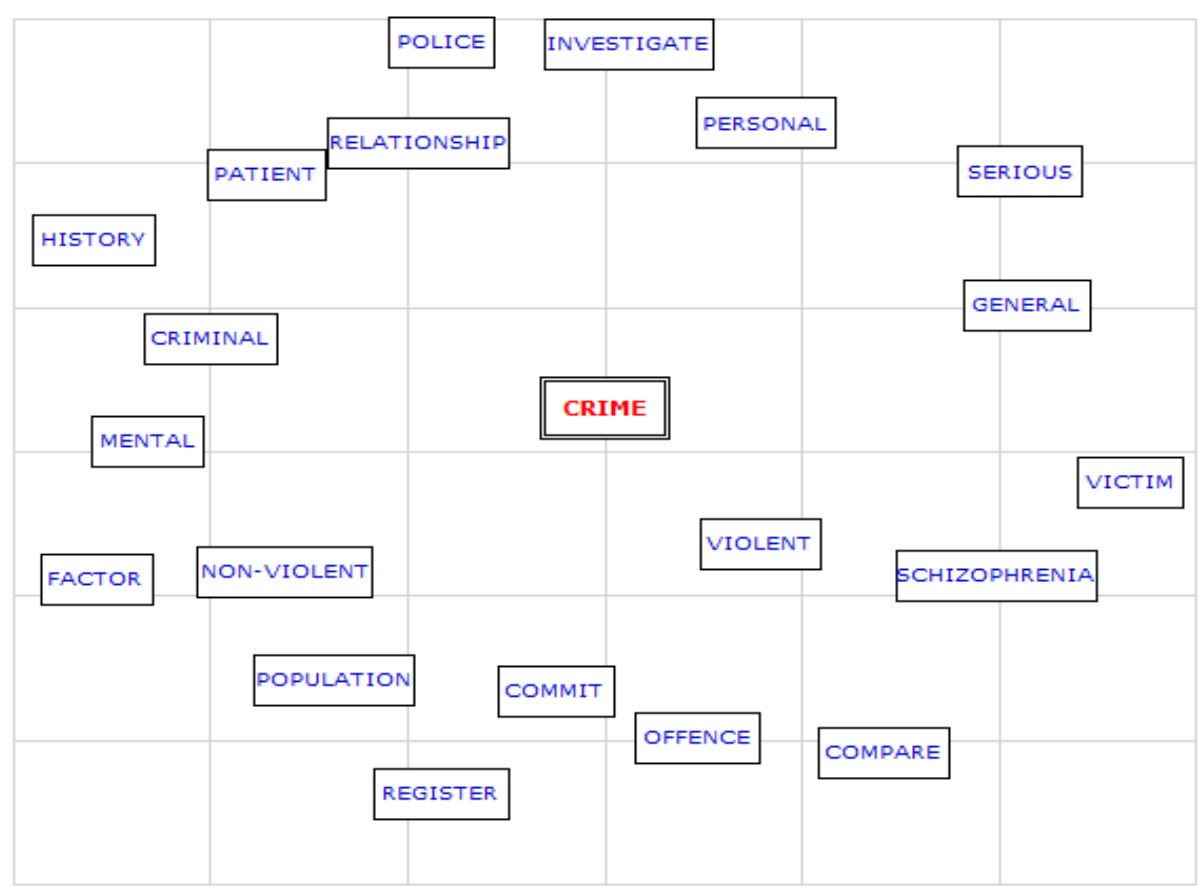

Furthermore, while the former was connected to a lexicon that echoed problems and their relevant difficulties ('abnormality', 'handicap', 'disorder', 'severe', 'serious', 'problem'), and with the domain of services-structures ('service', 'hospital', 'professional', 'patient', 'state'), the latter referred to the investigative ('police', 'investigate', 'history') and cognitive side of research ('factor', 'register', 'population', 'general', 'compare’).

\subsection{Discourse analysis}

The problematic and dilemmatic nature of the themes considered in the forensic psychiatry papers already found through Content Analysis preponderantly emerged from the Discourse Analysis. The analysis of the whole corpus of articles in the forty-year period emphasized the increasing complexity of the argumentation through two macro-environments of contents and discursive strategies: in other words, through two "social-epistemic rhetoric". These double macro-functions frame the analyzed texts balance between the "social reassurance" and the "awareness of the limits".

\subsection{The rhetoric of social reassurance}

The objective of the scientific communication was to produce reliable and valid theoretical-methodological frameworks and research contexts, in order to obtain control margins and predictability. Furthermore, in this field, some proposed contents were "applicable" to the daily life of people: if some information regarding a disease or a treatment was proposed as "certain", the scientific community was 
more likely to transform words into reality; if uncertainty should prevail, the application of those cognitions will be enacted more "cautiously".

Most of the time, the opening words of papers emphasized the social relevance of the proposed themes through assertive strategies, such as the references to public and social life, to services and to legislation as well as to mass media. This trend complied with the "mission" assigned to the introduction in a scientific paper, which was mainly aimed at establishing the author's "research territory" and at creating a "niche" for their contribution to occupy (Gross, Harmon, \& Reidy, 2002).

The position within a "niche" is usually supported through "quotations". This practice provided a solid grounding and a powerful enhancement of the proposed claims. Although quotations mainly showed what we can label a "problematiccritical" nature - aimed at highlighting the many possible scenarios and thus at keeping a high level of debate - they sometimes took an "assertive-narrative" object. In this case, they could guarantee the impression of being "grounded" in the scientific tradition and endorsed by some external" forms of legitimation (e.g. previous empirical evidences showing similar results and/or proposing consonant perspectives). Beside quotations, further external references were indicated, e.g. authorities or public services. They had the additional function of reassuring the interlocutors also in the "ethical" domain, in accordance with the scientific field.

In general, the "rhetoric of reassurance" was foremost established in the methodological approach. This kind of "methodolatry" sought a high degree of precision, through the references to percentage data and statistical analysis. In example 1 , this mode offered the opportunity to compare the "values" concerning different pathologies, thus giving more credibility and certainty thanks to the use of the shared code of figures.

Ex. 1: "Humphreys et al. (1992) estimated that 20\% [...] Volavka et al. (1997) estimated that $20 \%$ [...] Of the $17 \%$ of patients with a diagnosis of schizophrenia, $9 \%$ were violent in the first 20 weeks after discharge. This compares with a violence prevalence of $19 \%$ for depression, $15 \%$ for bipolar disorder, $17.2 \%$ for other psychotic disorders, $29 \%$ for substance misuse disorders and $25 \%$ for personality disorder alone” (Walsh et al., 2002, p. 491).

Other recurrent rhetorical strategies adopted by the authors of the texts to "assure" and "convince" the readers about the validity of their assumptions consisted of precise illustrations of the procedures, as well as of the exposition of the reasons for each choice. In this way, the reader was involved "behind the scenes" of the research, to further enhance the construction of a trust agreement with the scientific community.

More generally, the rhetoric of reassurance was carried out by textual metadiscourse markers, such as logic connectors, gloss practices ('however', 'also', 'in addition', 'therefore'), frame and endophoric markers ('for example', 'for two reasons', 'for three reasons', 'three main implications'). These linguistic expressions anticipated and/or state authors' intentions about the structure and evolution of the text; therefore, they favored the construction of expectations and enable a more aware reading of the same. The efforts to provide precise and meticulous 
demonstrations, combined with the use of the meta-discourse, gave strength to argumentation, as it was based on legitimation and justification.

Though, while the textual meta-discourse principally acted upon the organizational level of the discourse, in the attempt to make clear connections, definitions and conclusion, authors also used the relational meta-discourse that was more clearly oriented to establish a relationship of trust between them and the ideal scientific community to whom their texts were addressed,. This objective was pursued by means of some specific argumentative strategies:

a) the strategy of sincerity, enabling the authors to either articulate reasons or provide clarifying inserts, sometimes contrasting even among themselves (e.g. "In contrast to one of our initial hypotheses");

b) the strategy of dialogism, which allows the authors to take in adequate esteem others' positioning (Hermans and Gieser, 2012) and to exhibit the capacity of dialogue among the various claims;

c) the strategy of collaboration, aimed to emphasize the "collaborative" nature of their own approach, as well as the "constructive" function of knowledge of their own text, considering the "model reader".

The whole corpus was characterized by the efforts of connection with the territorial services which operate prevention, treatment and/or detention: they were constructed through proposals, suggestions, references to duties and responsibilities, attempts to provide economic quantification of (missing) interventions and to attribute a numerical value to more "qualitative" factors.

\subsection{The Rhetoric of Limitation}

The social-epistemic rhetoric of "social reassurance" was mainly focused on the construction of an interpretative proposal of the dangerousness of the mentally ill as much "certain" as possible. To this purpose, in most sections the papers justified the limits of their own work, in line with the complexity of forensic psychiatry.

This function was constructed by means of various argumentative strategies working both "explicitly" and "implicitly". Sometimes long and argumentative lists of limits were found, expressed by lexical and syntactical expressions evidently related to uncertainty: for example, "Nevertheless, there is still uncertainty about [...] It is doubtful whether it should be [...] The ethical dilemma remains". Otherwise the provided explanations were presented as "uncertain", "possible" or "potential". Furthermore, their work was framed in a mainly incomplete scenario, made up of partial considerations, failures, lack of details. Therefore, it was almost impossible for readers to take a stance, to orient themselves and to seek certainties.

The rhetoric of the "limit" was also acted through the pragma-linguistic indicators of mitigation. In accordance with the "functional" typology proposed by Caffi (2001), "hedges" weakened the illocutionary force of the statements. They operated through modelizers of the epistemic commitment (Kochelman, 2007) (e.g. "perhaps", "probably"), subjectivizing (and thus restricting) epistemic certainties as well as through a massive use of modal verbs (at the conditional mode). On the 
other hand, "bushes" decreased the enunciator's commitment to the contents by means of negation ("It is important not to be constrained by") and mitigated choices of lexicon, such as approximations ("somewhat", "approximately").

The social-epistemic rhetoric of the "limit" was also detectable through more holistic strategies aimed at reducing the range, the value or the certainty of their claims. These modes operated at a textual level and assumed an essential role, since they were focused on validating the argumentation:

a) rearranging the hierarchy, which consists of attributing importance to a rationale with the aim of replacing another one (e.g. "It is therefore important to highlight that the pathways and mechanisms leading to violence in patients with schizophrenia should not be reduced to one set of risk factors");

b) dilution, that is grading the level of precision. In other words, the Grice's maxim of quantity (1975) is openly violated, by using phrases such as "This usually involves [...] but is intended to [...] more were known [...] It is generally assumed that... often";

c) lateralisation, which enables to extend the range of possibilities. Sometimes it may also act as exemplification, thus making a case "one of many" (e.g.: "For example, a child psychiatrist may be unimpressed [...] But a criminologist or epidemiologist might take...”).

As for the space-time management, authors can also "keep the distance" from the exposed position through the paradigm of eventuality: in this case, they aimed at opening possible worlds by constructing hypothetical statements. The texts presented many references and projections on future scenarios as possible contexts for doubt resolution. These discursive acts emphasized the impossibility of setting certainties "here and now" for the limited, partial or precarious results.

In addition, we found a continuous argumentation swinging, which ended up assuming a "sinusoidal" trend. In particular, this fluctuation involved both the assertive/uncertain style throughout the text and the "confirmation"/“disconfirmation" intention carried out by the literature. It even happened that the same factor was firstly assessed in terms of convenience and then in terms of problems, that being "the first" to have performed a certain activity represents either a source of pride, or a necessary cautious mention. This sinusoidal trend can create a feeling of "precariousness", in opposition with any search for stability and cognitive closure. Most of times, authors can even keep the distance from their own results and explicitly invoke "caution", especially when the application of results is at stake.

\section{Discussion and Concluding Remarks}

Forensic psychiatry must accept the challenges provided by two worlds that have to reciprocally enhance for an ambitious enjeu, namely the search for stability, order and justice. Discursive practices primarily try to give order to distant requests and domains as well as to settle disputes and problems. In the discursive "genre" examined here - the scientific paper - texts have a well-structured form that makes it reliable to the reader. 
Dealing with the connections between psycho-pathological epidemiology and criminal behaviors, the enunciators proceed through an "assertive" and rigorous mode, in the attempt to produce effective contributions to the theoretical and empirical debate. Overall, the strategies adopted support the social-epistemic rhetoric of "reassurance" because the articles provide cognitive guarantees to the scientific community, firstly by connecting the accuracy of the proposed work to the solidity of the reported literature.

However, the research on social dangerousness of the mentally ill persons fails the cognitive "closure" that would come from the application of its results to the services, the institutional contexts and the pertinent laws. The so complex issues at stake suggest the enunciators to give voice/words to the social-epistemic rhetoric of the "limit". It operates in many ways, ranging from the role of the quotations in the introductions to the many declared shortcomings at the end of the paper. The authors confer a limited significance to their own results, with few certainties and much food for thought, deferring the possibility of contributing to decisive choices or actions to another (future) text; therefore, they avoid assuming definitive responsibilities and propose marginal applications for their results. In addition, expressions showing modesty, honesty and prudence are often recurrent. Such caution is suggested by the desire to obtain approval within the scientific community and to reduce the probability of criticism or refusal while encouraging a space of discussion between experts. This also means to emphasize the limits of scientific knowledge and to clearly inform the judicial system, redefining its expectations and interventions.

Our research tried to investigate the (un)certainties of law and psychiatry. The two social-epistemic rhetoric indicated in this paper corroborate the awareness that, in assessing the social dangerousness of the mentally ill person, the eventual "judicial" measures - claimed through the communicative register of law and justice - had to connect with the communicative language and register of the "socialsanitary" sciences in order to ascertain the mental functioning of the perpetrator and of the victim of crime, and to relate it to the context. For this reason, the forensicpsychiatric and psychological evaluation resulted also as a narration, an activity that focuses on the semantics, on the processes of symbolization and on the attribution used by the actors. It is time for the clinical world of psychology and psychiatry to better integrate with the forensic one: even if the hope of such an integration is accompanied by uncertainty, the probability of its success exceeds the one of tossing a coin.

\section{References}

Bakhtin, M.M. (1979). Estetika Slovesnogo Tvorcestva [Aesthetics of Verbal Creativiveness]. Moskow: Iskusstvo.

Bennett, T., Holloway, K., \& Farrington, D. (2008). The statistical association between drug misuse and crime: A meta-analysis. Aggression and Violent Behavior, 13, 107-118. https://doi.org/10.1016/j.avb.2008.02.001 
Berlin, J.A. (1993). Post-structuralism, semiotics, and social-epistemic rhetoric: Converging agendas. In T. Enos \& S. Brown (Eds.), Defining the new rhetoric (pp. 137-176). Newbury Park, CA: Sage.

Caffi, C. (2001). La mitigazione. Un approccio pragmatico alla comunicazione nei contesti terapeutici [Mitigation. A pragmatic approach to communication within therapeutic contexts]. Münster: LIT Verlag.

Cantarini, S., Abraham, W., \& Leiss, E. (Eds.) (2014). Certainty-uncertainty - and the Attitudinal Space in Between [SLCS 165]. Amsterdam: John Benjamin.

Catanesi, R., Carabellese, F., \& Grattagliano, I. (2009). Cura e controllo. Come cambia la pericolosità sociale psichiatrica [Treatment and control. How has the concept of psychiatric social danger changed]. Giornale Italiano di Psicopatologia, 15, 64-74. Retrieved from https://www.jpsychopathol.it/article/treatment-and-control-how-has-the-concept-ofpsychiatric-social-danger-changed

Crismore, A., Markannen, R., \& Steffenson, M. (1993). Metadiscourse in persuasive writing: A study of texts written in American and Finnish University students. Written Communication, 10(1), 39-71. https://doi.org/10.1177/0741088393010001002

Fairclough, N. (2003). Analysing Discourse: Textual Analysis for Social Research. London: Routledge.

Foucault, M. (1972). The Archaeology of Knowledge and The Discourse on Language. New York: Pantheon Books.

Grevi, V. (2006). Prove [Proof]. In V. Grevi \& G. Conso (Eds.), Compendio di procedura penale [Handbook of penal procedure] (pp. 313-406). Padua: Cedam.

Grice, P.H. (1975). Logic and conversation. In P. Cole \& J.L. Morgan (Eds.), Syntax and semantics, Vol. 3: Speech acts (pp. 41-58). New York: Academic Press.

Gross, A.G., Harmon, J.E., \& Reidy, M.S. (2002). Communicating Science. The Scientific Paper from the 17th Century to the Present. New York: Oxford University Press.

Hermans, H. J. M., \& Gieser, T. (Eds.). (2012). Handbook of Dialogical Self Theory. Cambridge, U.K.: Cambridge University Press.

Hyland, K. (1996). Writing without conviction? Hedging in scientific research articles. Applied Linguistics, 17(4), 433-454. https://doi.org/10.1093/applin/17.4.433

Hyland, K. (1998). Boosting, hedging and the negotiation of academic knowledge. TEXT\&Talk, 18(3), 349-382. https://doi.org/10.1515/text.1.1998.18.3.349

Hyland, K. (2001). Bringing in the reader: addressee features in academic articles. Written Communication, 18(4), 549-574. https://doi.org/10.1177/0741088301018004005

Junginger, J. (1996), Psychosis and violence: the case for a content analysis of psychotic experience. Schizophrenia Bulletin, 22, 91-103. https://doi.org/10.1093/schbul/22.1.91

Kaliski, S.Z. (2002). A comparison of risk factors for habitual violence in pre-trial subjects. Acta Psychiatrica Scandinavica, 106(412), 58-61. https://doi.org/10.1034/j.1600-0447.106.s412.13.x

Kockelman, P. (2007) Agency: The Relation between Meaning, Power, and Knowledge. Current Anthropology, 48(3), 375-401. Retrieved from http://www.jstor.org/stable/10.1086/512998

Lamb, H., \& Weimberger, L. (1998). Persons with severe mental illness in jails and prisons: A review. Psychiatric Services, 49, 483-492. https://doi.org/10.1176/ps.49.4.483

Lancia, F. (2004). Strumenti per l'analisi dei testi. Introduzione all'uso di T-LAB [Instruments for Text Analysis. Introduction to the Use of T-LAB]. Milano: Franco Angeli.

Lindqvist, P., \& Allebeck, P. (1990), Schizophrenia and crime: a longitudinal follow-up of 644 schizophrenics in Stockolm. British Journal of Psychiatry, 157, 345-350. https://doi.org/10.1192/bjp.157.3.345

Marzuk, P. (1996), Violence, crime and mental illness: How strong a link? Archives of General Psychiatry, 53, 481-486. https://doi.org/10.1001/archpsyc.1996.01830060021003.

Mininni, G., \& Manuti, A. (2017). A rose is more than a rose... The diatextual constitution of subjects and objects. Text \& Talk, 37(2), 243-263. https://doi.org/10.1515/text-2017-0005 
Mininni, G., Manuti, A., Scardigno, R., Rubino, R. (2014). Old roots, new branches: The shoot of diatextual analysis. Qualitative Research in Psychology, 11, 1-16. https://doi.org/10.1080/14780887.2014.925996

Mininni, G., Scardigno, R. \& Grattagliano, I. (2014). The dialogic construction of certainty in legal contexts. Language \& Dialogue. Special issue Certainty and Uncertainty in dialogue, 4(1), 112-131. https://doi.org/10.1075/ld.4.1.07min

Monahan, J. (1997). Clinical and actuarial predictions of violence. In D. Faigman, D. Kaye \& M. Saxs (Eds.) Modern scientific evidence: the law and science of expert testimony (pp. 300318). New York: West.

Mullen, P. (2000). Forensic mental health. British Journal of Psychiatry, 176, 307-311. https://doi.org/10.1016/s0160-2527(00)00057-1

Rasanen, P., Tiihonen, J., Isohanni, M. (1998). Schizophrenia, alcohol abuse and violent behaviour: A 26-year follow-up study of an unselected birth cohort. Schizophrenia Bulletin, 24, 437-41. https://doi.org/10.1093/oxfordjournals.schbul.a033338

Salvatore, S., Gelo, O.C., Gennaro, A., Metrangolo, R., Terrone, G., Pace, V., Venuleo, C., Venezia, A., \& Ciavolino, E. (2017). An automated method of content analysis for psychotherapy research: A further validation. Psychotherapy Research, 27(1), 38-50. https://doi.org/10.1080/10503307.2015.1072282

Salvatore, S., \& Valsiner, J. (2011). Idiographic science as a nonexisting object: The importance of the reality of the dynamic system. In S. Salvatore, J. Valsiner, A. Gennaro, \& J.B. Travers Simon, (Eds.), YIS: Yearbook of idiographic science (Vol. 3) (pp. 7-26). Rome: Firera \& Liuzzo.

Shah, S.A. (1978). Dangerousness and Mental Ilness: Some Conceptual, Prediction and Policy Dilemmas. In C. Frederick (Ed.) Dangerous behaviour: A problem in Law and mental health (pp. 153-191). Rockville, MD: NIMH, Washington.

Steadman, H. J., \& Cocozza J. J. (1974). Careers of the criminally insane: Excessive social control of deviance. Lexington, MA: Lexington Books, D.C. Heath.

Swanson, J., Estroff, S., Swartz, M., Borum, R., Lachicotte, W., Zimmer C., \& Wagner, R. (1997). Violence and severe mental disorder in clinical and community populations: the effects of psychotic symptoms, comorbidity and lack of treatment. Psychiatry, 60, 1-22. https://doi.org/10.1080/00332747.1997.11024781

Swartz, M., Swanson, J., \& Hiday, V. (1998), Violence and severe mental illness: The effects of substance abuse and nonadherence to medication. American Journal of Psychiatry, 155, 226-231. https://doi.org/10.1176/ajp.155.2.226

Torrey, E. (1994). Violent behaviour by individuals with serious mental illness. Hospital \& Community Psychiatry, 45, 653-662. https://doi.org/10.1176/ps.45.7.653

Valsiner, J. (2007). Culture in minds and societies. Foundations of cultural psychology. New Delhi: Sage.

Van Dijk, T.A. (2008). Discourse and Power. Houndsmills: Palgrave.

Walsh, E., Buchanan, A., \& Fahy, T. (2002). Violence and schizophrenia: examining the evidence. British Journal of Psychiatry, 180, 490-495. https://doi.org/10.1192/bjp.180.6.490

Wodak, R., \& Meyer, M. (2009). Methods of critical discourse analysis. Thousand Oaks, CA: Sage. 